\title{
Improving Students' Spatial Skill with Learning Cycle Using Cabri 3D Application in Junior High School
}

\author{
Malim Muhammad ${ }^{1}$ \\ Joko Purwanto ${ }^{2}$ \\ Rizqi Muji Prisnaini ${ }^{3}$
${ }^{1}$ Universitas Muhammadiyah Purwokerto, malim.muhammad@gmail.com
${ }^{2}$ Universitas Muhammadiyah Purwokerto, jokotien@gmail.com
${ }^{3}$ Universitas Muhammadiyah Purwokerto,rizqimp031@gmail.com

\begin{abstract}
This research aims to improve spatial skills of students on the subjects of 3-dimensional geometry with Learning Cycle Model using application Cabri 3D in Junior High School Muhammadiyah Ajibarang. This research is Classroom Action Research that implemented in the 3 cycles where each cycle consists of 2 hours of the first meeting to deliver material, 2 hours at the second meeting to convey material and then the last one hour to test evaluation. The subject of this research is 32 students of seven-grade junior high school Muhammadiyah Ajibarang. Each cycle in this research starting from the action planning, implementation of the action, observation, evaluation, and reflection. The technique of data collection that researchers have already done is observation and tests of spatial skills of mathematics students. Based on the results of research, the spatial skills of students at the first cycle obtained the average score of 67.50 , the second cycle obtained the average score of 79.06 and third cycle obtained the average score of 85.00 . The conclusions from this study are learning using Learning Cycle Model using application Cabri 3D can improve the spatial skills students of seven-grade junior high school Muhammadiyah Ajibarang particularly on the subjects of 3-dimensional geometry than shown by increasing of average score student's spatial skills tests every cycle.
\end{abstract}

Keywords: Spatial Skills, Learning Cycle Model, Cabri 3D

\section{PRELIMINARY}

According to the Fadilah and Afifah (2014), geometry is a standard content in the school curriculum and should be fulfilled in learning mathematics with the varies portion according to the level where learn about points, lines, areas, and objects of space with its properties and their relationship to each other. Geometry establishes spatial ability because of the ability to capture appropriately the space area that characteristic of spatial intelligence students. Thus researchers do a test to measure the extent which spatial abilities of the student with criteria of some indicators spatial reasoning skills include: (1) Spatial Perception, (2) Spatial Visualisation, (3) Mental Rotation, (4) Spatial Relation, and (5) Spatial Orientation. Learning mathematics in Junior High School Muhammadiyah Ajibarang particularly on class seven-grade still using conventional learning means that the learning is still centered on the teacher, so the role of the student, in this case, less effect on learning. This is the results of students seven-grade in Junior High School Muhammadiyah Ajibarang about mastery polyhedron before prior to treating using contextual learning as follows
Table 1. Initialization Spatial Skills of Students

\begin{tabular}{|c|l|c|c|c|c|c|c|}
\hline No & \multirow{2}{*}{$\begin{array}{c}\text { Students' Spatial } \\
\text { Indicators }\end{array}$} & \multirow{2}{*}{$\begin{array}{c}\text { Score } \\
\text { Average }\end{array}$} & $\begin{array}{c}\text { Very } \\
\text { Low }\end{array}$ & Low & Adequate & High & $\begin{array}{c}\text { Very } \\
\text { High }\end{array}$ \\
\hline 1 & Spatial Perception & 54.68 & & & $\sqrt{ }$ & & \\
\hline 2 & $\begin{array}{l}\text { Spatial } \\
\text { Visualisation }\end{array}$ & 40.62 & & & $\sqrt{ }$ & & \\
\hline 3 & Mental Rotation & 42.18 & & & $\sqrt{ }$ & & \\
\hline 4 & Spatial Relation & 31.25 & & $\sqrt{ }$ & & & \\
\hline 5 & Spatial Orientation & 45.31 & & & $\sqrt{ }$ & & \\
\hline
\end{tabular}

From the above results, it is seen that the spatial ability of students on the five indicators of the subject of 3-dimensional geometry is still in the category adequate and less. The average student is still having trouble solving problems based on the five spatial skills indicators. Teacher expectation from the average of five indicators of students' mathematical spatial ability from high to very high criteria that range of values 61 to 100 . Therefore, to improve spatial ability students need a model in learning. One of them is using Learning Cycle with 3D Cabri application which is a learning media that can be used to help teachers especially on learning geometry. Because Cabri 3D makes it easy for students to understand abstract mathematical problems to be easier to understand. With the steps in the Learning Cycle where each stage can improve the indicators of spatial ability in students. 
According to Wena (2011: 19), Learning Cycle is a student-centered learning, Agustyaningrum (2011) stated that learning mathematics using Learning Cycle is able to make grade 9 students of SMP Negeri 2 Sleman have good mathematical communication ability. Stages in Learning Cycle can improve students' mathematical communication skills. The first stage of engagement, exploration, explanation, elaboration, and evaluation, with the implementation of learning, the percentage of students' mathematical communication ability increased from $56.50 \%$ in 1 st cycle to $69.21 \%$ in 2 nd cycle (has reached the high category according to the observation sheet) and according to test result, students' mathematical communication ability also increase from $63.58 \%$ in $1 \mathrm{st}$ cycle to $70.11 \%$ in 2 nd cycle (have reached adequate category). The study observed students' mathematical communication, while the spatial abilities of students have not been observed. Therefore, it arises the idea how when the Learning Cycle applied to the subjects of mathematics in particular to improve students' spatial abilities.

\section{THEORETICAL REVIEW}

According to Armstrong (in Yuliani and Bambang, 2010) spatial ability is the ability to visualize images in one's thinking. Sulistyarini and Santoso (2015) stated that spatial ability is the intelligence of thinking in the form of visualization, drawing and three-dimensional form, whereas according to Yaumi (2013: 16) spatial ability is the sensitivity to line, color, shape, space, balance, pattern, and relationship between the elements. Other components are the ability to imagine, present ideas visually and spatially and orientate appropriately. The core component of spatial intelligence rests on the viewing sharpness and observational accuracy.

From the three opinions of experts above can be concluded that spatial ability is the ability to respond to an object in a different position by visualizing the forms of three-dimensional and two-dimensional space. The ability to focus on the sharpness of the view on the threedimensional space when rotated. By prioritizing the accuracy of the observations so as to be able to present the spatial idea accurately and appropriately oriented. The spatial capability indicators as follows: (1) Spatial Perception, (2) Spatial Visualisation, (3) Mental Rotation, (4) Spatial Relation, and (5) Spatial Orientation.

According to Moyer RH (2007:12), Learning Cycle model is one of the student-centered learning models. Learning cycle is a series of stages of activities organized so that learners can master the competencies that must be achieved in learning. The learning cycle initially consists of three stages of activity, namely exploration phase, concept introduction, concept application. However, the three-phase Learning Cycle has now been developed into five phases, namely the added engagement stage at the beginning of the cycle and the evaluation stage at the end of the cycle. In this lesson, the concept introduction and concept application phases are termed explanations and elaborations, so the current Learning Cycle is often called "Learning Cycle 5-E". The steps of the Learning Cycle model are as follows: (1) Engagement stage, (2) Exploration stage, (3) Explanation stage, (4) Elaboration stage and (5) Evaluation stage.

The word media comes from the Latin medius which literally means 'middle', 'intermediary' or 'introduction'. So it can be interpreted that the media is something that lies in the middle (between two sides or poles) or a tool. According to Yunus Johan et al (2015), the media is used as a communication tool to improve teaching and learning process. As explained by Martin and Briggs (in Wena, 2009), the media are all the necessary resources to communicate with students. Media can be hardware such as computers, televisions, projectors, and software used on the device. Cabri 3D is a dynamic geometry software that can be used to help students and teachers to overcome some of the difficulties in learning 3-dimensional geometry and make learning three-dimensional geometry easier and more interesting.

\section{RESEARCH METHODS}

The research was conducted in Junior High School Muhammadiyah Ajibarang by taking the subject of geometry and measurement, while its implementation in the even semester of academic year 2016/2017. Steps in planning are as follows:

a. The researcher along with the teacher establishes Learning Cycle by establishing 3D Cabri as an assisted learning tool.

b. Creating a Learning Plan for 6 units for 6 meetings on geometry and measurement materials with Learning Cycle.

c. Produce a pretest problem in the form of multiple choice as a form of initial result of student's knowledge before any treatment.

d. Creating Student Worksheet (SW) relates to learning materials at the meeting.

e. Making the evaluation test is essay related to the indicator of spatial ability of 3 units and given at the end of each cycle.

f. Create an observation sheet of teacher and student activity.

During the learning process takes place the teacher teaches with the Lesson plan which has been prepared by the researcher using Learning Cycle on the subject of geometry and measurement. Observation activities conducted with the aim to observe teacher activity and 
student activities in the learning process. Observation of teachers is an observation of teacher activity in the learning process in accordance with the stages of the Learning Cycle, while student observation is an observation of student activity at the time of following the learning process. The researcher has prepared observation sheet of teacher and student, researcher assisted by observer doing an observation on the course of learning and recording all observation result both at teacher observation sheet and also student observation sheet.

1. Evaluation of research implementation

a. Evaluation of teacher activity, this evaluation is used to find out teacher activity using Learning Cycle as Activity Sheet Observation Sheet. Sheet evaluation of teacher activity that has not succeeded that if score obtained average only reach adequate category that is with score 2 and category less than with score 1 . While evaluation of activity of teacher that has the success that if score got average reaching high category that is with a score of 3 and a very high category that is with a score 4 . The results of the evaluation that has not been successful should be fixed in the next cycle.

b. Evaluation of student activities, this evaluation is used to know the student activity during the learning process by using Learning Cycle in the form of Student Activity Observation Sheet. Sheet evaluation of student activity that has not succeeded that if score obtained average only reach adequate category that is with score 2 and less category that is with score 1 . While evaluation of student activity which has succeeded that if score obtained average reaching high category that is with a score of 3 and a very good category that is with a score 4 . The results of the evaluation that has not been successful should be fixed in the next cycle.

c. Evaluation of the spatial ability of students, this evaluation is used to determine the level of spatial ability of students that is a test at each end of the cycle by referring 5 indicators of the spatial ability of students which each indicator consists of 1 test evaluation questions.

\section{Reflection}

At this stage, all the results of observation and evaluation are processed and reflected to measure success rates and know the weaknesses of action implementation during one cycle. At this stage it improves the less-thanachieving evaluations on teacher and student activity, and then the evaluation results are used to plan the next cycle action.

\section{RESULTS AND DISCUSSION}

Based on the results of research from the implementation of the 1 st cycle until the 3rd cycle of learning through Learning Cycle model assisted Cabri 3D then can be described as follows:

1. Observation of teacher activity

In every cycle such as the 1 st cycle to the 2 nd cycle, in general, the activities performed by the teacher are improved. The teacher is trying to carry out activities that have not been implemented in previous cycles, such as in conveying the learning objectives and motivating the students. Similarly, what happens to the 2 nd cycle activity to the 3rd cycle the more activities the teacher performs. activities that have not been done in cycle 1 are better in the 2 nd cycle and the 3 rd cycle is then reflected. The result of teacher activity observation is better because teacher activity is getting improved in every cycle. The teacher explains using the Cabri 3D about cubes and beams to explain the concept of point position, line, field and its size in three-dimensional spaces, so that spatial ability increases.

2. Observation of student activities

In every cycle like cycle 1 to 3 rd cycle, in general, the activities performed by the students are improved, it is seen that the students progressively carry out activities that are not implemented in previous cycles, for example in doing individual test which in cycle 1 still cooperates a lot then on the 2nd and 3rd cycle the students are getting more orderly in doing individual test. Similarly, what happens to the activity of the 2 nd cycle to the 3 rd cycle of the activities done more perfect. Things that have not been done in cycle 1 are improved in the 2nd cycle and the $3 \mathrm{rd}$ cycle is then reflected. The result of student activity observation is better because student activity is improved in every cycle. Students are better able to imagine cubes and beams and their elements such as the position of dots, lines, planes in three-dimensional spaces using Cabri 3D.

3. Test students' spatial abilities

The researchers gave spatial ability tests to students at each end of the cycle. The results of students' spatial ability tests can be seen in the following table:

Table 2. Average Scores of Spatial Capability of Each Student Cycle

\begin{tabular}{|c|c|c|}
\hline Cycle & Average & Criteria \\
\hline 1st & 67.50 & High \\
\hline 2nd & 79.06 & High \\
\hline 3rd & 85.00 & Very High \\
\hline
\end{tabular}

Based on table 2 the results of students' spatial ability tests have increased in each cycle. The above data are presented in graphical form as follows: 


\section{Figure 1. Graph of Average Scores of Spatial Ability of} Students

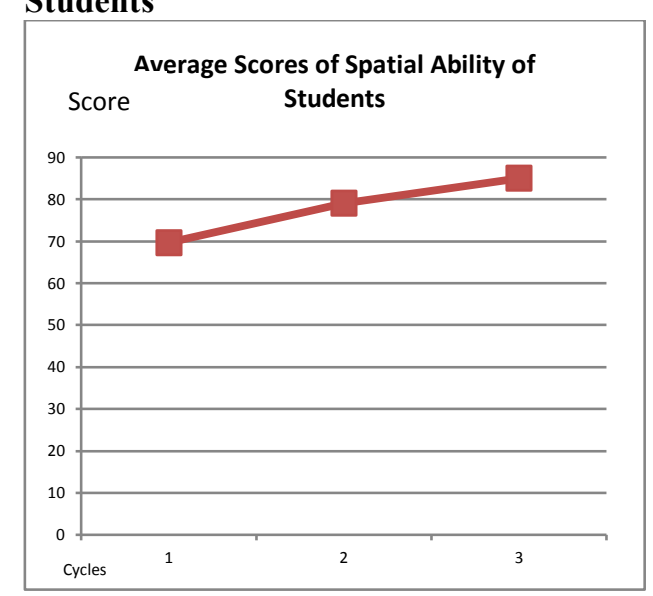

Based on Figure 2 it is known that students' spatial abilities from the 1 st to 3 rd cycle have increased. The improved result of spatial ability test of cycle 1 to cycle 2 with the difference of 11,56 from 67,50 to 79,06 , while the improvement of the result of student spatial ability test of cycle 2 to cycle 3 with difference 5,94 is from 79.06 to 85.00 . The result of students' spatial ability test obtained the average value of each indicator from cycle 1 to 3 rd cycle in class 9 of SMP Muhammadiyah Ajibarang can be seen in the following table:

Table 3. Average Scores of Spatial Ability of Each Indicator

\begin{tabular}{|l|l|l|l|l|}
\hline Number & Indicator & 1 st Cycle & 2nd Cycle & 3rd Cycle \\
\hline 1 & $\begin{array}{l}\text { 1st } \\
\text { Indicator }\end{array}$ & 1.3 & 1.7 & 1.8 \\
\hline 2 & $\begin{array}{l}\text { 2nd } \\
\text { Indicator }\end{array}$ & 1.4 & 1.4 & 1.7 \\
\hline 3 & $\begin{array}{l}\text { 3rd } \\
\text { Indicator }\end{array}$ & 1.3 & 1.5 & 1.6 \\
\hline 4 & $\begin{array}{l}\text { 4th } \\
\text { Indicator }\end{array}$ & 1.5 & 1.6 & 1.7 \\
\hline 5 & $\begin{array}{l}\text { th } \\
\text { Indicator }\end{array}$ & 1.5 & 1.7 & 1.8 \\
\hline
\end{tabular}

The results of the average value of each indicator can be presented in the form of images as follows:
Figure 2. Mean Average Spatial Capacity of Each Indicator

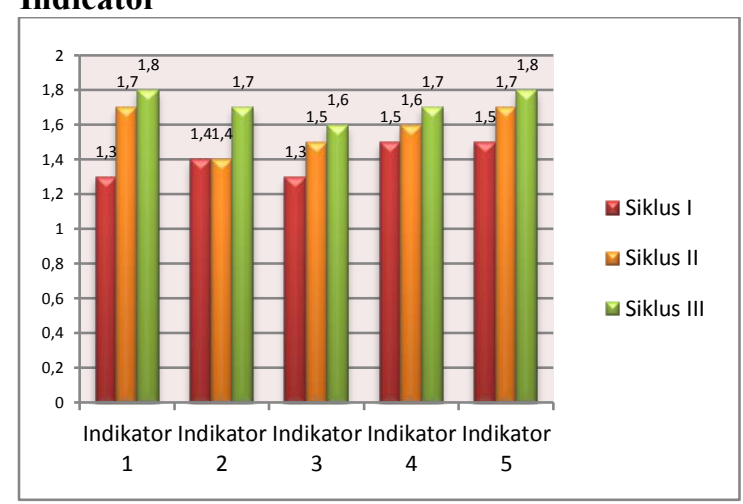

From figure 2 we get the average score of students' spatial ability indicator with the resulting increase from the 1 st cycle up to the 3 rd cycle. This is influenced by teacher activity and student activity during the learning process. The teacher has performed activities in accordance with the lesson plan. These activities are the initial activities (engagement stage), core activities (exploration stage, explanation stage, elaboration stage) and final activity (evaluation stage). These activities have been carried out by the teacher at each meeting and have increased in each cycle. In addition, students also increasingly understand the material that is learned and have tried to practice spatial skills well during the learning process using the learning cycle model, especially in the elaboration stage that is when the use of Cabri 3D in each cycle. It is shown that the students are able to understand the position of the point, the line, the field and its sizes. This is in line with the opinion of Rudhito and Larasari that the student's abstraction power can be increased by Cabri 3D. In addition, students are also trained to work in groups. It can increase cooperation and tolerance among students.

Based on the above, it can be concluded that the learning cycle model assisted by Cabri 3D application can improve spatial ability of Student grade 7F in Junior High School Muhammadiyah Ajibarang.

\section{CONCLUSION AND SUGGESTION}

\section{A. Conclusion}

Based on the results of research and discussion that has been described can be concluded that learning using Learning Cycle model assisted Cabri 3D application can improve the spatial ability of students grade 7F in Junior High School Muhammadiyah Ajibarang especially on the subject of 3-dimensional geometry. This is indicated by the increase of the average score of students 'spatial ability test that is on the 1st cycle the average score of students' spatial ability is 67.50 with high criteria. Then the 2nd cycle average score of students' spatial ability increased to 
79.06 with high criteria and in the 3rd cycle to 85.00 with very high criteria.

\section{B. Suggestions}

Based on the classroom action research that has been carried out on the 7F grade student in Junior High School Muhammadiyah Ajibarang, the researcher conveys some suggestions as follows:

1. Teachers should pay more attention to the time between dividing groups by giving conclusions after group discussion.

2. Teachers should be more disciplined and firm in the division of groups, because it will reduce the time in doing student evaluation activities.

\section{REFERENCES}

Accascina, G. dan Rogora, E. (2006). "Using Cabri 3D Diagrams For Teaching Geometry”. 13, (1), 3-9

Agustyaningrum, N. (2011). "Implementasi Model Pembelajaran Learning Cycle 5E Untuk Meningkatkan Kemampuan Komunikasi Matematis Siswa Kelas IX B SMP Negeri 2 Sleman”. Jurusan Pendidikan Matematika, Pascasarjana Universitas Negeri Yogyakarta. $978-979-16353-6-3,382-385$

Alhadad, I. (2013). "Peningkatan Kemampuan Pemecahan Masalah Matematis Melalui Model Siklus Belajar (Learning Cycle)". Jurnal matematika dan pendidikan matematika. 2, (1), 46-55.

Arikunto, S. dan Jabar, S.A. (2010). Evaluasi Program Pendidikan. Jakarta : Bumi Aksara

Dansa, I.W. dan Fajaroh, F. (2007). Pembelajaran Dengan Model Siklus Belajar (Learning Cycle). [Online].

Fadilah, E.N. dan Afifah, D.S.N. (2014). "kecerdasan visual-spasial siswa smp dalam memahami Bangun ruang ditinjau dari perbedaan kemampuan Matematika". Jurnal Pendidikan Matematika STKIP PGRI Sidoarjo. 2, (2), 151-159
Irsadi, dkk. (2016). "Penggunaan Perangkat Lunak Cabri $3 D$ Pada Pokok Bahasan Bangun Ruang Sisi Lengkung di Kelas IX SMP N 24 Palembang"

Maier, P.H. (1996). "Spatial geometry and spatial abilityhow to make solid geometry solid?"

Moyer, RH. dkk. (2007). Teaching Science as Invertigations Modeling Inquiry

Through Learning Cycle Lessons. Columbus: Pearson

Prabowo, A. dan Ristiani, E. (2011). "Rancang Bangun Instrumen Tes Kemampuan Keruangan Pengembangan Tes Kemampuan Keruangan Hubert Maier dan Identifikasi Penskoran Berdasar Teori Van Hielle". Jurnal Kreano FMIPA UNNES. 2, (2), 72-87

Runisah, dkk. (2017). "Using the 5e learning cycle with metacognitive Technique to enhance students'mathematical". International Journal on Emerging Mathematics Education (IJEME). 1, (1), 87-98

Shoimin, A. (2014). 68 Model Pembelajaan Inovatif dalam Kurikulum 2013. Yogyakarta: Ar-ruzz media.

Sujiono, Y.N. dan Sujiono, B. (2010). Bermain Kreatif Berbasis Kecerdasan Jamak. Jakarta: Indeks.

Sulistyarini, M.M. dan Santoso, F.G.I. (2015). "Pengaruh kecerdasan visual-spasial terhadap hasil belajar matematika dalam problem based learning pada siswa sma kelas X”. 1, (1), 56-72

Wena, M. (2011). Strategi Pembelajaran Inovatif Kontemporer (seri kelima). Jakarta: Bumi Aksara.

Yaumi, M. dan Ibrahim, N. (2013). Pembelajaran Berbasis Kecerdasan Jamak (Multiple Intelligences) Mengidentifikasi dan Mengembangkan Multitalenta Anak. Jakarta: kencana.

Yunus, J. dkk. (2015). "Penggunaan Software Cabri 3D Pada Materi Bangun Ruang Sisi Datar Kelas VIII SMPN 6 Banda Aceh". Prosiding Seminar Nasional FKIP Universitas Syiah Kuala. 978-602-97671-8-6, 122-123 